АРХЕТИПИ ГРЕЦЬКИХ МІФІВ У ФЕШН-ДИЗАЙНІ ХХІ СТ. З ПОЗИЦІЙ МЕТАМОДЕРНІЗМУ

Ірина Гардабхадзе, https://orcid.org/0000-0002-8899-3267 WoS Researcher ID AAH-7880-2021 доцент, старший науковий співробітник,

Київський національний університет культури і мистецтв, Київ, Україна irene.gard.fd@gmail.com

Анна Антонова, студентка кафедри мистецтв, Київський університет культури,

Київ, Україна lev.anna.at@gmail.com

\section{ARCHETYPES OF GREEK MYTHS IN THE FASHION DESIGN OF THE XXI CENTURY FROM A METAMODERN VIEWPOINT}

\section{Iryna Gardabkhadze,} https://orcid.org/0000-0002-8899-3267

WoS Researcher ID AAH-7880-2021

Associate Professor,

Senior researcher,

Kyiv National University of Culture and Arts Kyiv, Ukraine

irene.gard.fd@gmail.com

\section{Anna Antonova,}

Student of the Department of Arts, Kyiv University of Culture,

Kyiv, Ukraine

lev.anna.at@gmail.com

\section{Анотація}

Мета статті полягає у з'ясуванні особливостей функціонування архетипових структур (у даному разі - архетипів грецьких міфів) у сучасному фешн-дизайні; а також в аналізі особливостей розвитку методології проєктування фешн-дизайну з позицій метамодернізму. Методологія дослідження. Проблема аналізу особливостей розвитку фешн-дизайну у контексті метамодернізму вирішена на базі міждисциплінарного системного аналізу з комбінуванням предметного, історіографічного і морфологічного аналізів. Наукова новизна. У дослідженні запропоновано прийоми синтезу елементів образів героїв грецьких міфів з елементами-носіями сучасної моди з урахуванням тенденцій метамодернізму. Експериментальна перевірка результатів дослідження проведена шляхом оцінки художньо-естетичних якостей моделей колекції сучасного жіночого одягу за мотивами грецьких міфів. Висновки. У результаті дослідження доходимо висновку, що у практиці фешн-дизайну проєктний підхід доцільно вирішувати зба-

\section{Abstract}

The purpose of the article consists in clarifying the features of the archetypal structures functioning (in this case archetypes of Greek myths) in modern fashion design and also in the analysis of the fashion design methodology peculiarities in the conditions of metamodernism. The realization of this purpose is planned by developing the method of designing modern clothing, taking into account the principles and characteristics of metamodernism. Research methodology. The complex problem of analyzing the features of fashion design development in the environment of metamodernism is solved based on interdisciplinary system analysis with a combination of subject, historiographic and morphological analyzes.Scientific novelty. For the first time, it was shown that modern design trends, such as in-personal empathy and situational expressiveness, more careful consideration of aesthetic guidelines, psychological attitudes, and user expectations, are most harmoniously reflected in the principles of metamodernism. It was demonstrated that in the conceptual 
лансовано між факторами творчого першоджерела, особистих якостей індивіда і проявлених у ньому архетипів. Для експериментального підтвердження результатів обрано характерні елементи образів грецьких богів, які було закладено у якості креативного потенціалу в основу для розробки моделей сучасного одягу. Таким чином результати проєктування колекції підтвердили доцільність звертання до архетипових форм для пошуку інноваційних дизайнерських рішень. space of the metamodern, the principle of oscillation corresponds to a choice between two competing primary sources of an image generation in fashion design. The images of Greek mythology gods were chosen as traditional elements of the design project, and prototypes of modern clothing models were chosen as competitive elements. Conclusions. As a result of the research, we conclude that in the practice of fashion design, it is expedient to solve the project approach in a balanced way between the factors of the creative source, the personal qualities of the individual, and the archetypes manifested in it. The methods for elements of Greek myths heroes' images synthesizing with elements-carriers of fashion trends was proposed, taking into account the tendencies of metamodernism. Experimental approbation of the research results was carried out by assessing the artistic and aesthetic qualities of modern women's clothing models collection based on Greek myths motives. Thus, the results of the collection design confirmed the feasibility of turning to archetypal forms to find innovative design solutions.

\section{Ключові слова: Keywords:}

фешн-дизайн, трансформація, метамодернізм, архетип, грецькі міфи, трансфер елементів образів. ism, archetype, Greek myths, transfer of image elements. fashion design, transformation, metamodern-

Вступ 1 На межі XX-XXI ст. у мистецтві з'являється численна кількість нових назв, у числі яких дослідники називають перформатизм, гіпермодернізм, реновалізм, автомодернізм, метамодернізм, дігімодернізм (Rudrum \& Stavris, 2015). Зародження нових течій у мистецтві було пов'язано з новими творчими методами, які відразу ж відображались і на тенденціях у дизайні, на визначенні його місця і функцій у сучасному цифровому середовищі. Актуальним стало питання, які з нових течій відобразяться на розвитку дизайну, а які відпадуть, так і не давши плодів.

Актуальністю визначення ролі і місця культури в адаптаційних процесах інформаційного суспільства зумовлено багато публікацій, значна частка яких присвячена зародженню нових напрямків культури і мистецтва та аналізу спонукальних факторів їхнього розвитку. Також треба констатувати популярність досліджень новітніх можливостей цифрового інструментарію архітектури, дизайну та інших напрямків декоративно-приклад- 
них мистецтв (Власов, 2015; Гардабхадзе, 2019; Гусейнов, 2017; Date et al., 2017).

Проте наразі не знайшло належного відображення у наукових публікаціях переосмислення ролі фешн-дизайну як агента багатомільярдної індустрії моди та виконавця функцій задоволення фундаментальних потреб індивіда. У фаховій періодиці останніх років практично відсутні матеріали, що присвячені аналізу ролі фешн-дизайну як носія гуманістичних принципів в умовах нових концепцій культур, про його вплив на формування естетичних орієнтирів сучасної людини, формування позитивного іміджу особистості засобами костюму. Актуальним залишається завдання дослідження особливостей розвитку і нових можливостей фешн-дизайну з позицій метамодернізму.

\section{Мета дослідження}

Метою статті є з'ясування особливостей функціонування архетипових структур (у даному разі - архетипів грецьких міфів) у сучасному фешн-дизайні з позицій метамодернізму. Завдання полягає в аналізі особливостей розвитку методології проєктування фешн-дизайну в сучасних умовах. Реалізація цієї мети запланована шляхом розробки методу проєктування сучасного одягу з урахуванням принципів і характерних рис метамодернізму. Експериментальна перевірка результатів дослідження здійснюється на базі розробки колекції сучасного жіночого одягу за мотивами архетипів образів богів грецьких міфів.

\section{Методологія та аналіз джерельної бази}

Ідея даної роботи продиктована актуальністю прогнозування траєкторії розвитку культури з позицій тенденцій її трансформації в умовах зміни культурних парадигм.

В основу дослідження покладена гіпотеза про фешн-дизайн як втілення задоволення естетичних потреб людини шляхом відображення гуманістичних ідеалів та естетичних настанов індивіда в дизайнерських рішеннях сучасного костюма. Це твердження є часткою більш загальної проблеми аналізу гомостатичного потенціалу культури в умовах трансформації засобом формування естетичних орієнтирів сприйняття візуального образу особистості.

Для дослідження складної проблеми аналізу особливостей розвитку і функціонування фешн-дизайну в контексті метамодернізму використано міждисциплінарний системний аналіз з комбінуванням предметного, історіографічного і морфологічного аналізів.

\footnotetext{
Результати дослідження

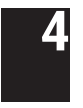

Аналіз особливостей розвитку методології проєктування фешн-дизайну в умовах метамодернізму. Протягом тисячоліть циклічного розвитку людської цивілізації періоди сталого розвитку змінювалися катаклізмами, які стимулювали зароджен- 
ня нового циклу. У мистецтві модель «маятника Чижевського», в основі якої лежить теорія чергування протилежних типів культури, повторює картину циклічності. Маятник Чижевського виділяє традиційні пари понять: ренесанс і бароко, класицизм і романтизм, реалізм і модернізм, причому ці поняття характеризують мистецтво з протилежних полюсів: «кожен перший член цих пар орієнтований на «зміст», другий - на «форму». Класицизм і романтизм в історії європейської культури означають два майже непримиренних полюси світогляду, а між реалізмом і модернізмом пролягає справжня прірва» (Власов, 2015, с. 10). Непарні члени послідовності - ренесанс, класицизм, реалізм представляють, згідно з Власовим, «об'єктивні стилі», парні бароко, романтизм, модернізм - «суб'єктивні стилі».

Проте завдяки циклічності розвитку мистецтва те, що не вдалося зробити за одну епоху, може реалізуватися в наступній, але досягатиметься в інший спосіб. Сучасна культура перебуває на порозі зміни парадигм. Після того, як постмодерн встиг зробити абсолютну істину умовною, деконструювати всі концепти інших культур, розібравши їх на елементи для копіювання, а також довів до втоми цими елементами, цитуванням і нескінченною рекурсією симулякрів, він втратив ключові позиції. Завдяки тому, що масова культура зробила людину заручником деконструкції і швидкого споживання продуктів рекурсії, суспільство відмовилося від старих орієнтирів, але епоха залишилася без базової платформи для трактування дійсності.

Чергова пара ланцюга моделі Чижевського - постмодернізм і пост-постмодернізм, не повною мірою відповідає цій тенденції, між цими поняттями немає прямої протилежності, «відстань» між ними за понятійною шкалою не збільшується. Варто зауважити, що у нової парадигми наразі немає стійкої назви. Ймовірно, що зміна парадигм перебуває у проміжній стадії, про що сигналізує безліч нових напрямків.

Закономірно виникають питання про причини і механізми змін парадигм культури. На рубежі століть людство досягло найвищих результатів у розчленуванні складних проблем на частини для їх детального вивчення. Однак у процесі розчленування системи на частини втрачається структура і зміст взаємозв'язків, тобто важлива частка інформації, завдяки якій синергія синтезу народжує з простої сукупності елементів систему з її емерджентністю. Це актуалізує «зворотну» проблему синтезу окремих частин у цілісну систему.

Якщо постмодерн зруйнував усі концепції попередніх культур до найдрібніших елементів, то стає актуальним завдання відтворення цілого з частин. Завдяки циклічності розвитку мистецтва те, що не вдалося зробити в одну епоху, може стати підставою творення в наступну, але досягатиметься інши- 
ми шляхами. I можна висловити припущення, що парадигма метамодерну більш сприятлива для такого процесу. Зокрема, притаманні йому емпатія та ситуаційна експресивність, ретельне врахування психологічних настанов, естетичних еталонів та очікувань споживачів створюють гармонійне підґрунтя й для фешн-дизайну.

Аналіз публікацій дозволив серед більшості сучасних течій визначити тенденції метамодернізму провідними у фешн-дизайні, зокрема, такі як емпатія та ситуаційна експресивність, ретельне врахування психологічних настанов, естетичних еталонів та очікувань користувачів. «Метамодерн рухається завдяки розгойдування між протилежностями. Він не займає певну позицію, а сприймає світ і культуру як один загальний потік змістів, які $€$ частинами загальної істини. Метамодерн не пропонує готову ідею або концепцію, а пропонує знайти ії самостійно, використовуючи «осцилюючий рух»» ("Метамодерн - новый", 2017). Саме за такими принципами розвивається й сучасний фешн-дизайн.

Дизайн як медіатор відносин «людина-природа» має індикативні властивості, які дозволяють результати його аналізу використовувати як «маркери» людських настроїв, транслюючи їх у сфери дослідження інших напрямків культури. 3 усіх напрямків дизайну до потреб та очікувань людини ближче за все - дизайн людського образу. Фешн-дизайн як основний компонент формування габітарного іміджу особистості безпосередньо пов'язаний зі створенням образу людини. Тому аналіз його ролі у трансформаційних процесах культури інформаційного суспільства становить особливо актуальну проблему.

Розгляд можливостей сучасного фешн-дизайну з позицій метамодернізму дозволив конкретизувати і властивості самої течії у дискурсі фешн-дизайну. Демонстрація характеристик фешн-дизайну як виконавця задоволення естетичних потреб індивіда реалізована шляхом відображення гуманістичних ідеалів та естетичних установок індивіда в дизайнерських рішеннях сучасного костюма.

Поняття «цільові групи споживачів» фешн-дизайну майже без спотворень сенсу може бути перенесено в термінологічно-понятійне середовище метамодернізму, який не нав'язує конкретним користувачам рішення, а пропонує спільно шукати їх серед розмаїття можливостей. Принцип осциляції вибору між двома конкуруючими першоджерелами народження образу відповідає актуальній тенденції сучасного фешн-дизайну у перенесенні акценту проєктування на творчий тандем «дизайнер-споживач» у процесі створення образу цього споживача. Таким чином гармонійна взаємодія понять і принципів може стати джерелом генерації нових художніх ідей і розширених 
можливостей функціонування фешн-дизайну в концептуальному просторі метамодерну.

Аналіз принципів метамодернізму дозволяє зробити висновок, що він розвивається у середовищі з множиною суперечливих емоцій, тенденцій, позицій і сценаріїв. У перекладі на проєктну мову фешн-дизайну, метамодернізму потрібні різні характерні першоджерела. У даній роботі середовищем для прояву метамодернізму вибрано сучасне фешн-середовище. У просторі проєкту потрібно знайти баланс між традиціями і новаціями, між елементами культурного надбання та елементами-носіями тенденцій моди, і в цьому просторі охарактеризувати фешн-дизайн у термінах метамодернізму як носія стабілізуючого потенціалу культури і виконавця потреб споживачів.

Аналіз перспектив трансферу елементів змісту грецької міфології для пошуку інноваційних дизайнерських рішень моделей сучасного жіночого одягу. Передбачається, що перспективними для трансферу будуть ті риси образів міфічних богів, які спроможні створити креативний потенціал для підвищення художньо-естетичних властивостей моделей сучасного одягу та будуть сприяти досягненню інноваційності дизайнерських рішень.

Як відомо, характерними носіями актуальних соціокультурних рис сучасності є узагальнені образи різних медійних або соціальних персонажів, які під впливом сюжетів стали виразниками певних ідей і ціннісних орієнтирів.

В історії людської культури значне місце займають легенди та міфи, які втілюють віковічну мудрість людства і допомагають транспонувати колективний досвід у новий стиль життя, прогнозувати події і долати труднощі змін. Легенди і міфи пробуджують у людей почуття і формують фундамент колективної свідомості, оскільки породжені сюжетами, які є частиною спільної спадщини людства. Так проявляється роль переказів у формуванні культурних стереотипів, нових аксіологічних орієнтирів та ідеалів.

Актуальність вибору для фешн-проєкту в стилі метамодернізму першоджерел-носіїв елементів культурної спадщини Стародавньої Греції підтверджується фактом, що зародження в історії людства нової ери супроводжується трансфером у нові умови життя легендарно-міфічного контенту, який надає еволюції суспільства гомеостатичний потенціал синтезу культурної спадщини з інноваціями науково-технічного прогресу і допомагає людям осягнути сучасність. Люди часто не усвідомлюють, який потужний імпульс для реалізації внутрішнього потенціалу дають легенди й образи їхніх героїв. Ці внутрішні образи, або архетипи, які протягом тисячоліть зберігаються у пам'яті людини, юнгіанський підхід до психології пов'язує з колективним несвідомим, яке лежить у психологічній основі особистості. 
Оскільки архетипові образи грецьких богів існують у людській уяві вже більше трьох тисячоліть, вони здаються нам «знайомими», тому що є частиною нашої колективної загальнолюдської спадщини. У книгах відомого психолога Джина Шинода Болена, у яких досліджується роль архетипів богів як у житті жінок (Болен, 2005), так і житті чоловіків (Болен, 2008), стверджується, що історії грецьких богів Олімпу є метафоричним відображенням внутрішнього різноманіття і внутрішніх конфліктів сучасної людини. «Богині живуть у внутрішньому світі сучасних жінок у якості архетипів і, претендуючи на повне панування над своїми підданими, як і в Стародавній Греції, беруть те, що їм належить. Жінка може протягом якогось часу або навіть все життя залишатися у владі певного архетипу, навіть не знаючи, кому саме з богинь вона служить» (Болен, 2005). Автор стверджує, що усвідомлення «свого» бога-архетипу з підсвідомості допомагає повніше реалізувати жінці життєвий потенціал. Тому асоціація з образами богів з грецької міфології є цінним джерелом натхнення для створення експресивних дизайнерських рішень костюму з підтримкою тенденцій метамодернізму, візуально узгоджених з закладеними в підсвідомості архетипами.

Оскільки від вибору і гармонійної адаптації елементів образів першоджерел залежить художня виразність дизайнерських рішень моделей колекції, для вибору характерних рис образів богів, які є перспективними для трансферу у дизайнерські рішення сучасного одягу, за матеріалами літературних джерел було проаналізовано міфічні образи окремих богинь.

Стародавня Греція - осередок зародження сучасної цивілізації, основоположниця базових ідей та ідеалів. Античність наскрізь просякнута міфами. Для сучасної культури європейських народів антична греко-римська міфологія є певною культурологічною нормою.

Грецькі боги схожі на людей, їхній спосіб життя мало чим відрізнявся від людського, їм притаманні усі людські якості, у тому числі й негативні. Головна відмінність небожителів полягала в їхньому безсмерті та надприродній могутності. Таке антропоморфне уявлення греків про своїх богів неминуче викликало відповідне ставлення до них - в їхніх очах боги були зрозумілими людиноподібними істотами. Для греків моральне не відокремлювалося від прекрасного. Вони цінували й розуміли красу як природне вираження порядку речей, природну доцільність.

Для грецьких богинь як прототипів незалежної, потужної та впевненої у своїх можливостях жінки є характерним, а для деяких богинь ключовим є образ жінки-завойовниці, але такі чесноти, як ніжність і жіночність ще яскравіше проявляють досконалість і підкреслюють величність жіночого образу. 
У результаті аналізу для трансферу у дизайн моделей сучасного жіночого одягу були обрані характерні елементи образів богів грецької міфології, які видаються перспективними для використання у дизайні сучасного одягу

Найбільш характерними рисами вбрання грецьких богинь є складки і драпірування, які можна вважати найперспективнішими елементами першоджерела для трансферу в дизайнерські рішення сучасного одягу.

Тема грецької міфології у творчості відомих фешн-дизайнерів у стилі метамодернізму. У процесі створення авторських колекцій одягу звернення до так званих «пережитків минулого», які закарбовані в колективній пам'яті культурної спадщини, є поштовхом для створення «майбутнього».

Аналіз матеріалів різноманітних джерел з тематики, яка так чи інакше пов'язана з грецькими міфами, від викладу міфів, їхнього трактування до літератури, в якій розкриваються механізми впливу міфів на психологічні настанови та поведінку особистості в сучасних умовах, дозволяє стверджувати, що казково-романтичний, фантастичний і одночасно реалістичний наратив міфів $€$ невичерпним джерелом натхнення для творчості в різних напрямках культури.

Коментуючи колекцію високої моди Валентино «Весна 2016» (Valentino Haute Couture Spring 2016), провідний критик фешн-порталу Vogue.com Capa Мовер (Sarah Mower) зазначила, що кутюр'є вдається подолати кілька протиріч: одне з них - протиріччя між вимогами до щосезонної новизни колекцій і впізнаваності почерку будинку моди, інше - між вічними культурними надбаннями старовини і сучасністю молодості: «Неймовірні речі, які дизайнери можуть робити з тканиною, роблять кожну сукню парадоксом старовинної ручної роботи і юнацької простоти (...). Екзотичний венеційсько-язичницький романтизм початку XX-го ст. був легко вшитий у колекцію Valentino Haute Couture i супроводжувався босими німфами з золотими металевими зміями, що звиваються в їхніх скуйовджених локонах» (Mower, 2016).

Мотиви даної колекції в іншому есе трактуються як «урок історії італійського мистецтва», а «босоногі німфи з золотими металевими зміями в їхніх скуйовджених локонах» безпосередньо асоціюються з образом Медузи-Горгони з волоссям у вигляді змій. Гармонійний баланс традицій і новацій у моделях колекції Валентино (Mower, 2016) досягається трансфером міфічних образів культурної спадщини у сучасне фешн-середовище з подальшими осциляціями між елементами старовини і елементами-носіями тенденцій моди (рис. 1).

Отже, результати аналізу тенденцій моди за 2020-2021 рр. засвідчують, що грецька міфологія є унікальним джерелом натхнен- 


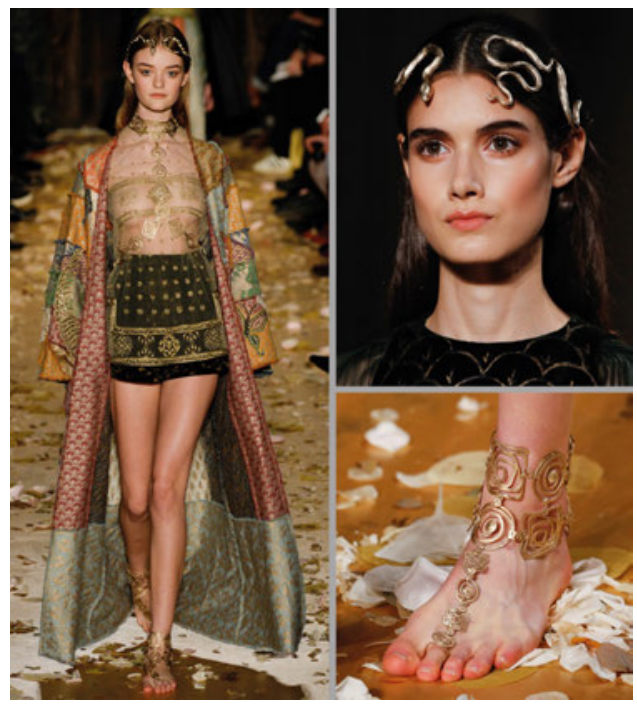

Рис 1. Модель і їі деталі колекції высокої моди Валентино «Весна 2016». Джерело: https://www.vogue.com/fashion-shows/ spring-2016-couture/valentino

Fig. 1. Model and its details of Valentino haute couture Spring 2016 collection. Source: https://www.vogue.com/fashion-shows/ spring-2016-couture/valentino

ня для дизайнерів, що цілком відповідає основним принципам метамодернізму. Основна ідея образів першоджерела співзвучна композиційним рішенням як верхнього, так і легкого ошатного одягу. У дизайнерських рішеннях простежуються тенденції на розробку і демонстрацію цих асортиментних груп, а також більш стриманих у своїй подачі образів для створення повсякденного неформального одягу. Особливо ефективне застосування образів грецьких богинь для розробки вечірніх суконь, оскільки саме цей асортимент одягу ідеально поєднує у собі жіночність, красу, силу духу та впевненість у власних можливостях, тобто ті риси, які так яскраво відображаються у грецьких богинь.

Пошук прийомів синтезу елементів образів героїв грецьких міфів з елементами-носіями тенденцій моди. Мистецтвознавчий аналіз надає дизайнерові стартову інформацію, яка поряд з маркетинговими даними і тенденціями моди бере участь у формуванні проєктного завдання. Крім стартової інформації про першоджерела генерації авторської ідеї і характеристики прототипів, мистецтвознавчий підхід пропонує методи для відбору, типізації та стилізації елементів першоджерела, які представлені інтермедіальним і морфологічним методами (Власов, 2012). Ці методи і підходи у сукупності спрямовані на трансфер елементів першоджерела (прототипу) в дизайнерські рішення, де за допомогою проєктного підходу стилізовані елементи образу першоджерела будуть використані як складові творчого синтезу з елементами-носіями естетичних, функціональних і утилітарних вимог до дизайну виробів.

Особливість фешн-дизайну у тому, що його цільовим об єктом є сама людина. Фешн-дизайн є в основі художнього образу особистості, що визначає його спрямованість до потреб людини. Цільова спрямованість на формування привабливого габітарно- 
го іміджу індивіда засобами костюма тягне за собою залежність фешн-дизайну як від природних особливостей та внутрішніх характеристик особистості, так і від соціальних стереотипів, найбільш значні з яких породжуються тенденціями моди.

Тобто ідея і реалізація кожного інноваційного фешн-проєкту спирається мінімум на два першоджерела генерації креативних дизайнерських рішень: одне з них є джерелом-носієм новизни і тому не пов'язане з поточними тенденціями, інше є прототипом з актуального фешн-середовища, джерелом-носієм тенденцій моди. Досягти інноваційності рішень і одночасно залишатися у рамках вимог тенденцій моди вдається шляхом гармонійної інтеграції цих джерел у процесі створення композиційних рішень моделей.

Але залишається ще один фактор впливу на результати проєктування. Потрібно адаптувати дизайнерські рішення до особистісних характеристик індивіда, або принаймні врахувати їх особливості для кожної з вузьких цільових груп. У даній роботі це досягається шляхом узгодження першоджерела з внутрішніми настановами особистості шляхом врахування впливу архетипів «колективного несвідомого» на особистісні переваги та психологічні установки індивіда.

Оскільки архетипи індукують певні внутрішні аспекти особистості, для самореалізації і повноцінного життя людині слід вибрати ту життєву роль, яка відповідає ії найактивнішому архетипу. «Боги» в такій якості виступають зразками для наслідування, здатними впливати на емоції й поведінку індивіда. I незважаючи на те, що кожна людина наділена унікальними рисами від природи і вони продовжують формуватися під впливом соціуму, можна помітити, що часто у ній проявляється певний архетиповий образ, який нагадує конкретного бога. І оскільки дизайн людського образу є найбільш близьким напрямом для особистості, для ії самореалізації важлива можливість через дизайн костюма слідувати тим внутрішнім установкам і естетичним орієнтирам, які закладені в її підсвідомості і асоціюються з архетипами певних богів.

Експериментальною перевіркою результатів даного дослідження стала розробка колекції моделей сучасного жіночого одягу за мотивами грецьких міфів. Робота була виконана на кафедри мистецтв Київського університету культури (рис. 2).

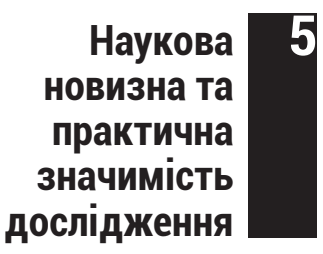

В дослідженні проведено аналіз перспектив трансферу елементів змісту грецької міфології для пошуку інноваційних дизайнерських рішень моделей сучасного жіночого одягу, аналіз теми грецької міфології у творчості відомих фешн-дизайнерів, запропоновано прийоми синтезу елементів образів героїв 

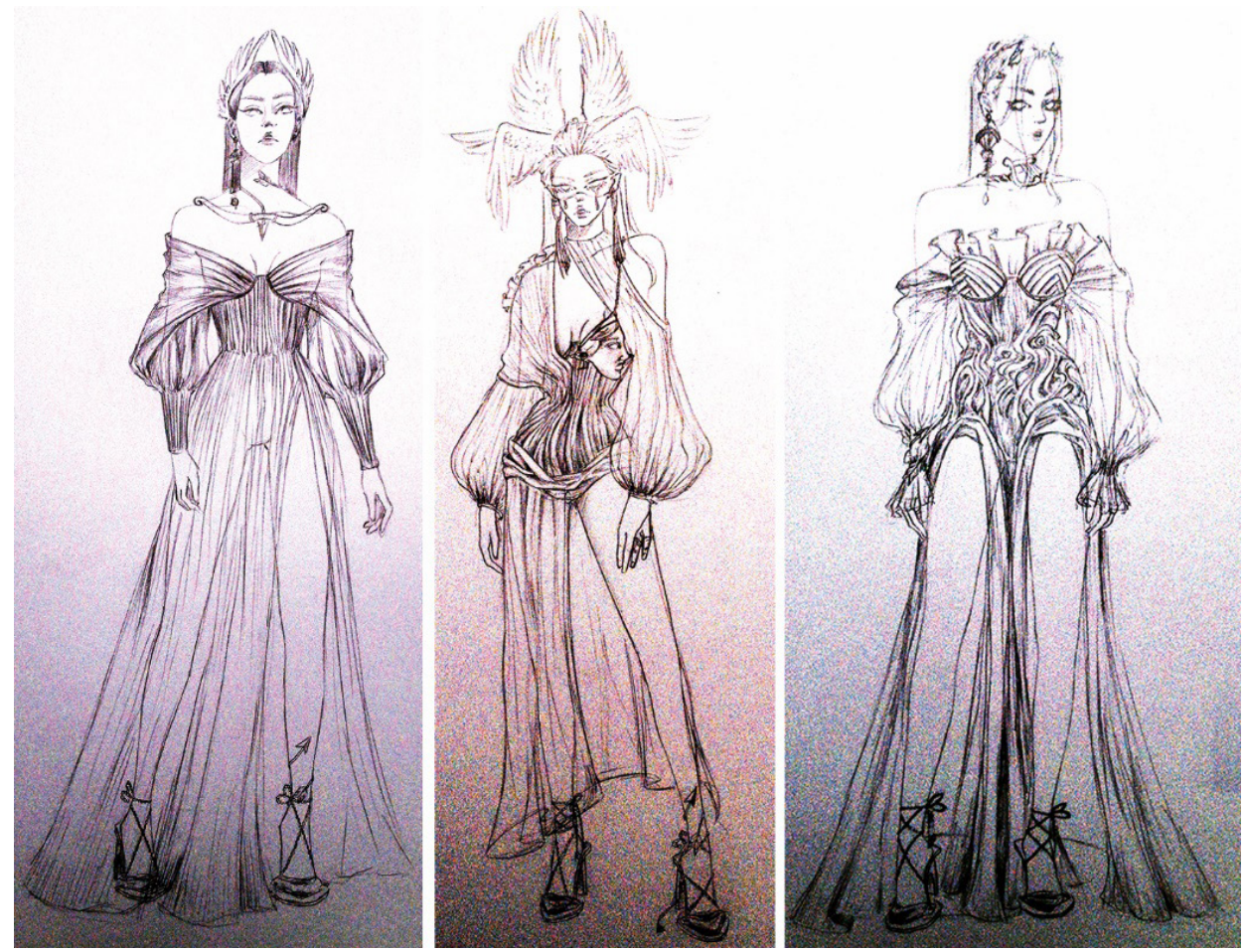

Рис. 2. Ескізи моделей колекції сучасного жіночого одягу за мотивами елементів образів богинь грецьких міфів. Авторська колекція сучасного жіночого одягу Анни Антонової, Київ, 2020.

Fig. 2. Sketches of models from modern women's clothing collection based on the elements of Greek myths goddesses' images. Author's women modern clothes collection by Anna Antonova, Kyiv, 2020

грецьких міфів з елементами-носіями сучасної моди з урахуванням тенденцій метамодернізму.

На прикладі конкретного фешн-проєкту показано, яким чином гармонійна взаємодія понять і принципів метамодернізму може стати джерелом генерації нових художніх ідей і розширених можливостей функціонування фешн-дизайну.

Висновки б У результаті дослідження доходимо висновку, що тенденції сучасного дизайну, такі як емпатія образу, ситуаційна експресивність, врахування естетичних орієнтирів, психологічних установок та очікувань користувачів, найбільш гармонійно відображаються в принципах метамодернізму. Зокрема, такий дизайн не нав'язує споживачам конкретні рішення, а пропонує спільно шукати їх серед розмаїття можливостей.

Результати аналізу теми грецької міфології у творчості відомих фешн-дизайнерів засвідчили перспективи подібних підхо- 
дів для інноваційних дизайнерських рішень моделей сучасного жіночого одягу. Доходимо висновку, що у практиці фешн-дизайну проєктний підхід доцільно орієнтувати на балансування трикутника факторів впливу, який утворений творчим першоджерелом, характеристиками особистості індивіда і певними архетиповими формами.

За допомогою аналізу наративу грецьких міфів було обрано характерні елементі, які лягли в основу розробки моделей сучасного одягу. У ролі традиційних елементів дизайн-проєкту обрані образи богів грецької міфології, у ролі конкурентних елементів - прототипи моделей сучасного одягу. У такий спосіб продемонстровано, що у концептуальному просторі метамодерного фешн-дизайну принцип осциляції відповідає вибору між двома конкуруючими першоджерелами народження образу.

\section{Список бібліографічних посилань}

Болен, Д. Ш. (2005). Богини в каждой женщине. Новая психология женщины. Архетипы богинь (Г. Бахтиярова \& О. Бахтияров, пер.). София.

Болен, Д. Ш. (2008). Боги в каждом мужчине. Архетипы, управляющие жизнью мужчин (Е. Мирошниченко, пер.). София.

Власов, В. Г. (2012). Параискусствознание и исторический процесс. Архитектон: известия вузов, 1(37). http://archvuz.ru/2012_1/4.

Власов, В. Г. (2015). Маятник Чижевского, или Как история убивает гениев. Добавления к теории прогрессивного циклического развития искусства Ф. И. Шмита. Архитектон: известия вузов, 1(49). http://archvuz.ru/2015_1/1.

Гардабхадзе, І. А. (2019). Імідж особистості в дискурсі соціальної адаптації в цифровій та постцифровій фазах розвитку інформаційного суспільства. Вісник Харківської державної академії культури. Серія: Соціальні комунікації, 57, 79-90. https://doi. org/10.31516/2410-5333.057.06.

Гусейнов, А. А. (2017). Будущее без будущего. В Глобальный мир: Системные сдвиги, вызовы и контуры будущего, XVII Международные Лихачевские научные чтения (с. 63-66). СПбГУП.

Метамодерн - новый способ смотреть на мир. (2017, 29 марта). Newtonew. https://newtonew. com/culture/wow-metamodern.

Date, P., Ganesan, A., \& Oates, T. (2017). Fashioning with Networks: Neural Style Transfer to Design Clothes. ML4Fashion. https://arxiv.org/pdf/1707.09899.pdf.

Mower, S. (2016, January 27). Valentino Spring 2016 couture. Vogue. https://www.vogue.com/ fashion-shows/spring-2016-couture/valentino.

Rudrum, D., \& Stavris, N. (Eds.). (2015). Supplanting the Postmodern: An Anthology of Writings on the Arts and Culture of the Early 21st Century. Bloomsbury Academic.

\section{References}

Bolen, J. S. (2005). Bogini v kazhdoi zhenshchine. Novaya psikhologiya zhenshchiny. Arkhetipy bogin' [Goddesses in Every Woman. New Psychology of Women. Archetypes of Goddesses] (G. Bakhtiyarova \& O. Bakhtiyarov, Trans.). Sofiya [in Russian]. 
Bolen, J. S. (2008). Bogi v kazhdom muzhchine. Arkhetipy, upravlyayushchie zhizn'yu muzhchin [Gods in Everyman: Archetypes That Shape Men's Lives] (E. Miroshnichenko, Trans.). Sofiya [in Russian].

Date, P., Ganesan, A., \& Oates, T. (2017). Fashioning with Networks: Neural Style Transfer to Design Clothes. ML4Fashion. https://arxiv.org/pdf/1707.09899.pdf [in English].

Guseinov, A. A. (2017). Budushchee bez budushchego [A Future Without a Future]. In Global'nyi mir: Sistemnye sdvigi, vyzovy i kontury budushchego [Global World: System Shifts, Challenges and Contours of the Future], XVII International Likhachev Scientific Readings (pp. 63-66). Saint-Petersburg University of the Humanities and Social Sciences [in Russian].

Hardabkhadze, I. A. (2019). Imidzh osobystosti $\vee$ dyskursi sotsialnoi adaptatsii $\vee$ tsyfrovii ta posttsyfrovii fazakh rozvytku informatsiinoho suspilstva [Personality Image in the Discourse of Social Adaptation in the Post-Digital Phase of Information Society]. Visnyk of Kharkiv State Academy of Culture. Series: Social Communications, 57, 79-90. https://doi. org/10.31516/2410-5333.057.06 [in Ukrainian].

Metamodern - novyi sposob smotret' na mir [Metamodern is a New Way of Looking at the World]. (2017, March 29). Newtonew. https://newtonew.com/culture/wow-metamodern [in Russian].

Mower, S. (2016, January 27). Valentino Spring 2016 Couture. Vogue. https://www.vogue.com/ fashion-shows/spring-2016-couture/valentino [in English].

Rudrum, D., \& Stavris, N. (Eds.). (2015). Supplanting the Postmodern: An Anthology of Writings on the Arts and Culture of the Early 21st Century. Bloomsbury Academic [in English].

Vlasov, V. G. (2012). Paraiskusstvoznanie i istoricheskii protsess [Para-'Art Study' and the Historical Process]. Architecton Proceedings of Higher Education, 1(37). http://archvuz.ru/2012_1/4/ [in Russian].

Vlasov, V. G. (2015). Mayatnik Chizhevskogo, ili Kak istoriya ubivaet geniev. Dobavleniya k teorii progressivnogo tsiklicheskogo razvitiya iskusstva F. I. Shmita [Chizhevsky Pendulum, or How History Kills Geniuses. Additions to The Theory of Progressive Cyclic Development of Art by F. I. Shmit]. Architecton Proceedings of Higher Education, 1(49). http://archvuz. ru/2015_1/1 [in Russian]. 